\title{
The transformation of the city of Zion: From decadence to justice and prophetic hope (Is. 1:1-2:5)
}

\begin{tabular}{|c|c|}
\hline $\begin{array}{l}\text { Author: } \\
\text { Alphonso Gro }\end{array}$ & newald ${ }^{1}$ \\
\hline $\begin{array}{l}\text { Affiliation: } \\
{ }^{1} \text { Department } \\
\text { Testament Stu } \\
\text { Theology, Uni } \\
\text { Pretoria, Sout }\end{array}$ & $\begin{array}{l}\text { f Old } \\
\text { dies, Faculty of } \\
\text { ersity of } \\
\text { Africa }\end{array}$ \\
\hline $\begin{array}{l}\text { Project leader } \\
\text { A. Groenewalc } \\
\text { Project numb }\end{array}$ & r: 02428024 \\
\hline $\begin{array}{l}\text { Description: } \\
\text { This research } \\
\text { project 'Exege } \\
\text { Theology of Is } \\
\text { by Prof. Dr Alp } \\
\text { Groenewald, } \\
\text { Old Testament } \\
\text { Faculty of The } \\
\text { University of P }\end{array}$ & $\begin{array}{l}\text { s part of the } \\
\text { sis and the } \\
\text { aiah', directed } \\
\text { honso } \\
\text { epartment of } \\
\text { Studies, } \\
\text { logy, } \\
\text { retoria. }\end{array}$ \\
\hline $\begin{array}{l}\text { Correspondin } \\
\text { Alphonso Gro } \\
\text { alphonso.groe } \\
\text { ac.za }\end{array}$ & $\begin{array}{l}\text { author: } \\
\text { newald, } \\
\text { newald@up. }\end{array}$ \\
\hline $\begin{array}{l}\text { Dates: } \\
\text { Received: } 21 \mathrm{~J} \\
\text { Accepted: } 21 \\
\text { Published: } 21\end{array}$ & $\begin{array}{l}\text { une } 2016 \\
\text { Aug. } 2016 \\
\text { Vov. } 2016\end{array}$ \\
\hline $\begin{array}{l}\text { How to cite th } \\
\text { Groenewald, } \\
\text { transformatio } \\
\text { Zion: From de } \\
\text { justice and pro } \\
\text { (Is. 1:1-2:5)', } \\
\text { Studies/Theol } \\
72(1) \text {, a3568. } \\
\text { org/10.4102/ }\end{array}$ & $\begin{array}{l}\text { is article: } \\
\text { 2016, 'The } \\
\text { of the city of } \\
\text { adence to } \\
\text { phetic hope } \\
\text { ITS Teologiese } \\
\text { gical Studies } \\
\text { tttp://dx.doi. } \\
\text { ts.v72i1.3568 }\end{array}$ \\
\hline $\begin{array}{l}\text { Copyright: } \\
\text { (C) 2016. The A } \\
\text { Licensee: AOS } \\
\text { is licensed unc } \\
\text { Creative Comr } \\
\text { Attribution Lic }\end{array}$ & $\begin{array}{l}\text { uthors. } \\
\text { S. This work } \\
\text { ler the } \\
\text { lons } \\
\text { ense. }\end{array}$ \\
\hline Read online: & \\
\hline 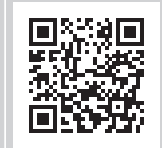 & $\begin{array}{l}\text { Scan this QR } \\
\text { code with your } \\
\text { smart phone or } \\
\text { mobile device } \\
\text { to read online. }\end{array}$ \\
\hline
\end{tabular}

This article focuses on the story of the transformation of the city called Zion. Isaiah 1:1-2:5 is the key to the book. This chapter describes the failure of Israel to be the people of God: Israel's covenant breach, a corrupted cult and imminent punishment. It tells of the existence of two groups within Israel: the righteous remnant who would be saved and the wicked who would be judged. This chapter furthermore presents the reader with a picture of decadent Jerusalem whose sacrifices are rejected and whose prayers are no longer accepted. Isaiah 1 contains a warning of judgement against Jerusalem, whereas Isaiah 2:1-5 sketches the prophetic hope for Zion, which would lead to a pilgrimage of the nations to receive the Torah on Zion.

\section{Introduction}

The prophetic literature of the Hebrew Bible has long been recognised as a source for social concern and justice. However, prophets and prophetic oracles were not unique to Israel and these types of figures played a prominent role in the societies of many nations across the Ancient Near East. Multiple parallels between the prophetic figures in Israel and Judah with these figures, for example, in the kingdom of Mari (18th century BCE) as well as during the neo-Assyrian empire (7th century BCE), have been established by scholars (cf. Nissinen 2000, 2003; Stökl 2012). A major difference however lies in the fact that the Hebrew prophetic literature is matchless in the fundamental priority it gives to social justice and issues of social concern in its message. This does not mean that there was no social concern, that is, a critique of sociopolitical and economic oppression, to be found at all in prophetic literature of the other Ancient Near Eastern nations. ${ }^{1}$ The important point is that the prominent position social concern had within the imagination of Israel's prophets is without comparison (Carrol 2009:35-36).

People who benefit from the status quo are not particularly welcoming of prophets in their midst. The prophetic voices are often the minority voices in a society and they oppose the ways of the majority in a specific society. They speak what is regarded as right and not what should be pleasant to hear (Is. 30:10). They are not smooth talkers and expose the injustices done against the powerless. They fearlessly expose inhumane and violent acts and demand redress for the victims of violence. Although they do not match the power of empires or national or institutional power, the oracles of prophets speak truth to power and instil hope in those who have lost hope. Although they are attached to a particular time and place, their visions cross temporal and physical boundaries. These visions travel from past to present, present to the future, and again back from the future to the past (Stulman \& Kim 2010:27-28).

Isaiah was such a prophet whose voice and vision called for mercy and justice for the nation's socially weak. He condemned the abuse of power by the leaders and reserved his severest critique for Judah's political and religious elite. To the Isaianic tradents - those for whom his warnings had become an awful reality in the light of the exile - his harsh oracles offer a reality check. Indeed, some of the proposed later additions to the book of Isaiah (BI) are clearly intended to support and maintain the radical witness of the older Isaiah so that his message may not be forgotten. Although these Isaianic oracles may have been painful to revisit, the tradents cherished them: 'they unrolled, read, reread, and rolled them again, hearing and reflecting on their meaning for subsequent generations' (Stulman \& Kim 2010:28).

1.In the letter of Nur-Sîn to Zimri-Lim we read the following: "I do not demand anything from you, When a wronged man or wo [man] cries out to you, be there and judge their case. This only I have demanded from you. If you do what I have written to you and heed my word, I will give you the land from the r[isi]ng of the sun to its setting, [your] land [greatly in]creased!' (Nissinen 2003:20).

Note: This article is part of the Special Collection titled 'Spatial Justice and Reconciliation', sub-edited by Stephan de Beer, of the Department of Practical Theology and the Centre for Contextual Ministry, University of Pretoria. 
Regarding the impact the exilic experience had and its subsequent influence on the development of the prophetic tradition, Carr (2011) infers as follows:

\begin{abstract}
As scholars have long supposed, such indictments - whenever they were written - were well suited for exiles attempting to come to terms with what had happened to them. Dated to the preexilic past, these prophetic traditions offered concrete diagnoses of where Israel and Judah went wrong. In this way, they helped exiles on the journey from shame to guilt, indicating possible wrong decisions that led to the catastrophe in which they now found themselves. This is the way prophetic literature of ancient Israel textualises what Robert K. Lifton has described as the feeling of 'failed enactment' among survivors of catastrophic trauma - replaying again and again the mistakes of the past in hope of achieving some kind of mental control over the incomprehensible present and recent past. (p. 300)
\end{abstract}

The Isaianic oracles contain the words and message of God directed towards nations, empires and institutions as well. They contain messages concerning justice and injustice, humiliation and suffering, survival and glimpses of faith and hope (Stulman \& Kim 2010:28). They inspire multiple audiences-including present-day interpretative communities who are addressed as participants in its 'implied audience ${ }^{2}-$ to become part of the Isaianic symbolic world 'in order to be transformed profoundly by that prophetic book' (Melugin 1996:305).

Conrad (1991:156-157) argues that the audience of the book is a community of survivors who have a minority status in the Judean society (cf. Is. 1:9). This community is clearly powerless, as is indicated by the characterisation of their opponents as leaders who are corrupt and inept (e.g. Is. 1:10, $23,26,27)$. The community is a community that suffers and is threatened by murder and bloodshed (e.g. Is. 1:21, 24). According to Smith-Christopher (2015:44; see also Carr 2014:67-90) one should not underestimate the impact suffering has on a community: therefore 'in biblical studies today, more than ever before, we are aware of the impact of traumatic events on individuals and groups'.

\section{The opening of the book of Isaiah: From decadence to justice and prophetic hope}

Isaiah 1:1-2:53 does not stand alone and should be read as part of the book as a whole. It is thus an introduction not only to the first main section of the book of Isaiah (BI; Is. 1-12) but to the whole book (Melugin 1996:295; see also Holladay 1978:46). According to Childs (2001:16) there is some

2.See Conrad (1996:325): 'as present interpreters of the book of Isaiah we are also its audience ...

3.For a justification for this subdivision, see Berges (2012b:59), Beuken (2003:89) and Groenewald (2013a:2). Compare furthermore the following observations Beuken (2004:457) made: 'The book of Isaiah (henceforth BI) opens with two paralle introductions in $1: 2-2: 5$ and $2: 6-4: 6$, which extend from Zion, the sinful city (1:21-27 and 2:8-3.26) to Zion, the mountain of $Y H W H$, where Torah is taught to $(1: 21-27$ and $2: 8-3: 26)$, to Zion, the mountain of YHWH, where Torah is taught to the nations (2:1-5) and Israel's remnant receives purification and shelter $(4: 2-6)$ This twofold convergence anticipates the development of both the prophetic boo as a whole and its foundational collection of prophecies, namely chs. 1-12. The chronological sequence of both oracles concerning Zion renewed is somewhat unusual: the first alluding to the city's attractiveness in the eyes of the nations
$(2: 1-5)$, the second alluding to its restoration as Israel's sacred abode $(4: 2-6)^{\prime}$. justification for form-critical analysis, given the fact that different genres are presented in this text (Sweeney 1996:101-123), but an important point is that these different units got a new role and function within a new literary context that is to be differentiated from their original function. ${ }^{4}$ Combined in their new literary context they now form an introduction to the book as a whole. Fohrer's (1962) important essay on Isaiah 1 opened a totally new direction in recent interpretation of the $\mathrm{BI}$ as he suggested that chapter 1 was an intentional composition and serves as a compendium of the rest of the BI. It presents a sequence of the book's major themes: sin, judgement and possible salvation. ${ }^{5}$

More recently, Carr (1996:204) questions whether chapter 1 is simply a summary; as some scholars have suggested. According to him Isaiah 1 not only presents the most important themes from the Isaianic tradition but, as it stands, presents a strategic reconceptualisation of this tradition. The first chapter of the book selected and remoulded the most relevant strands from the Isaianic tradition and formed a new theological whole out of them. This chapter therefore prepares the audience to hear subsequent Isaianic texts in a different way.

According to Childs (2001:17) this chapter in its present composition has a dominantly theocentric character: The focus in this chapter is neither on Isaiah (who is only a vehicle in the text) nor on Israel, but on God throughout the chapter. Isaiah 1 tells of YHWH's overwhelming anger towards Israel; it gives examples of Israel's rebellious behaviour, as well as telling about God's acts to bring Israel back to obedience. In this regard Childs (2001) furthermore infers:

The chapter concludes with the exercise of God's will both to punish and to restore Zion according to his own purpose. The dirge over the city is ended through an eschatological reversal that restores the faithful city. Zion's redemption is not just a 'possibility' (Fohrer) that is realized only by repentance, but a transformation derived solely from God, into which salvation Israel is invited to enter through true repentance. (p. 17)

The BI begins with a list of Israel's sins. Although YHWH raised and brought them up, they turned away from him and rebelled (פשע) against him (Is. 1:2, 28). For the BI this is the heart of the sin of Israel, who was called by God, but instead they rebelled against him and his will (Routledge 2004:188). Rebellion, for Isaiah, is sin. ${ }^{6}$ This is illustrated graphically by the fact that the BI begins and ends with references to

\footnotetext{
4.See also Carr (1996:198): "The approach taken here agrees with the latter overall thesis. More specifically, my thesis regarding 1.2-31 is that whatever the originally independent origins of the material, it has been molded into a whole now focused on encouraging a persistently faithless audience to cease their faithlessness and repent'.

5.In this regard, see Fohrer (1962:254): 'Inhaltlich bilden diese fünf vollständigen Worte der Sammlung einen gedanklich fortschreitenden Zusammenhang, der nacheinander die Themen der Sünde, des darum eintretenden Gerichts, der möglichen Rettung vor dem Verderben und einer möglichen Verwirklichung solcher Rettung berührt'.

6.See Kizhakkayil (2016:142): 'Rebellion (פשע) against YHWH is seen here as the first offence of the people. After the portrayal of rebellion in verses 2-3, the text proceeds to explain in two sets of three to four successive terms the wickedness of the people $(v 4 a-d)$ and their apostasy $(v 4 \mathrm{e}-\mathrm{g})$ against YHWH. Thus, verses $2-3$ is the people (v4a-d) and their apostasy $(\mathrm{v} 4 \mathrm{e}-\mathrm{g})$ against YHWH. Thus, verses $2-3$ is
also a springboard for the further presentation of the themes of wickedness and also a springboard for the further
apostasy of the people in verse $4^{\prime}$.
} 
rebellion $(1: 2 ; 66: 24)$. The presence of פשע [to rebel] in the opening and closing words of the BI suggests 'a conscious placement on the part of the final editor(s)' of this very important theme (Oswalt 1986:38).

The punishment that falls upon his rebellious children corresponds to the threats that YHWH had made, should his people break his covenant (Berges 2012a:26). At the end of the Torah, Israel is threatened that it would experience destruction equivalent to the destruction of Sodom and Gomorrah (Dt. 29:22; cf. Gn. 19:24-25). The allusion to this text is confirmed by the invocation of heaven and earth here at the beginning of the BI (1:2), which also occurs in this form at the beginning of the Song of Moses in Deuteronomy 32:1 (Groenewald 2011). The beginning of the BI is thus comparable to the end of the Torah (Dt. 32:28-29): YHWH regrets his people's lack of insight (Is. 1:3). According to Berges (2012a:26), 'by linking the BI to the curses and blessings of the Pentateuch, the tradents of the Isaiah tradition have turned Isaiah ben Amoz into a successor of Moses (Dt. 18.15, 18) and the prophetic scroll into an actualisation of the Mosaic Torah!'

In spite of Israel turning away from God, his actions are quite restrained. All of his children are not taken away and a small remnant (שָׁריד) still exists (1:9), that is, a community that would shape the future. This remnant introduces itself to the reader in the first person plural speech: 'Had YHWH Zebaoth not left us some survivors, we would be like Sodom, and we would be like Gomorrah!' (1:9). This important information confronts the reader from the beginning of the BI with the question of whether he or she would like to belong to the remnant (see $4: 3 ; 7: 22 ; 10: 20-22 ; 11: 11,16$ ), that is, the one 'within' with whom YHWH would perpetuate the history of his people. Only those within the community who turn away from their sin and return to YHWH (see 59:20) belong to the community of the remnant; subsequently only they belong to the disciples of Isaiah and the hearers of the BI (Berges 2012a:26-27).

Intermingled with Isaiah's vision of a wasted land is the vision of a failed leadership. Scattered throughout chapter 1 are the references to rulers (1:10), princes (1:23), judges (1:26) and counsellors (1:26) (Conrad 2003:200). Isaiah 1 presents the reader with a picture of a decadent Zion. The sacrifices that are offered in Zion cannot be accepted anymore; even the prayers coming from her must be turned away (Is. 1:11, 15) (Dumbrell 1985:112). The people and their leaders are portrayed as wicked by labelling them as leaders of Sodom and the people of Gomorrah (1:10) and their indulgence in murderous injustices justifies the rejection of their cult by YHWH. The association with Sodom and Gomorrah further develops the theme of the unwillingness of the people to listen to YHWH and his prophet, as well as the theme of their judgement (Kizhakkayil 2016:246).

The cultic and social criticism in Isaiah 1:10-15 is a reprimand of those cultic enthusiasts who would prefer sacrificial offerings over and above ethical conduct. This critique shows implicitly the reaction of postexilic Israel to its harsh reality and is obviously now of greater concern during the time of restoration. The instruction offered by the we-group in the name of the prophet Isaiah should not be seen as a total rejection of cultic sacrifice, but rather as a commitment to the priority of ethics over and above any form of sacrificial cultic activities. If $\mathrm{YHWH}$ accepted sacrifices from the hands of the wicked, he would be similar to a judge who accepts bribes (Berges 2012a:27, 2012b:53). According to Kizhakkayil (2016):

... the main thematic thrust of verse 11-15 could be summed up as follows: In verse 11-15, similar to Amos 5:21-25 .... the prophetic author says, that the empty rituals or sacrifices, coming to the temple, or religious festivals and the days of restraint, or even prayers, cannot save them, if they are done in tandem with grave iniquities and murderous injustices. (p. 179)

Several well-known passages, of which Isaiah 1:16-17 is one, demonstrate the centrality of social justice for the BI. This text conveys the command in a very powerful way that $\mathrm{YHWH}$ expects of his people - specifically the leadership - to take care of the needy and not to exploit their helplessness for personal gain. They should learn to do good, devote themselves to justice and take care of the rights of the widow and the orphan. Social sensitivity, as well as the obligation to social concern, are not an additional part of the message of the prophets, but are a substantive part of their message (Carroll 2009:36-37).

Verse 16 begins with the instruction 'wash yourselves; make yourselves clean', which is followed by a paraenesis focusing on the socio-ethical conduct of the hearers (Kizhakkayil 2016:179). Leclerc (2001:33) justly states that the close link that exists between cultic observance and ethical conduct is signalled by the terms to wash and clean. For Carroll (2009:37) it is possible to grasp the importance of issues of social concern by studying significant terms such as מִִ̣ [justice]

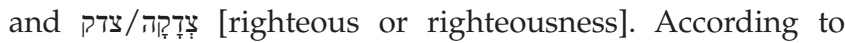

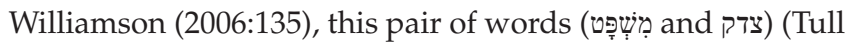
2010:68) gives expression to something close to the heart of Isaiah's concern. Isaiah unmistakeably regarded justice and righteousness as qualities characterising the ideal society, and verses $21 \mathrm{ff}$ demonstrate clearly that they were, in particular, the responsibility of the leaders of society. Justice and righteousness are not abstract nouns that are removed from the realities of everyday life, but they are deeply connected to the conviction that the proper ordering of society should reflect God's moral constitution (Carroll 2009:37).

This whole chapter is to be interpreted against the background of a struggle between two opposing groups within the people. The enemies thus do not come from the outside of the community but destroy it from within (see also Berges 2012a:27). The description of these two different groups becomes evident in 1:27-31, that is, there are those in Zion who will repent and will be redeemed by justice and by righteousness and those who will persist in their evil doings and will be burned up (1:28-31). The key to understanding this split in the people occurs in the Torah actualisation in 
1:10-17: this Torah calls upon the audience to repent (Carr 1996:198). The audience, after having received this command, is offered in 1:18-20 the same two choices with which the chapter concludes as well:

Come now, let us argue it out, says the Lord: though your sins are like scarlet, they shall be like snow; though they are red like crimson, they shall become like wool. If you are willing and obedient, you shall eat the good of the land; but if you refuse and rebel, you shall be devoured by the sword; for the mouth of the Lord has spoken. (NRSV)

Subsequently, Isaiah 1:2-31 can be summarised as follows: there is an overall movement from the people being accused (1:2-9) to a call to repentance (1:10-17). The rationale for this call is defined in the two subsections following (1:18-20 and 1:21-31), which both outline the outcome a choice for or against repentance has for the specific group or for the people. Within this literary context, one can understand the purging judgement in Jerusalem (1:21-26) as a description of the process of cleansing Zion from those who are doing evil, while - in contrast - those who repent will enjoy the purified city of Zion (Carr 1996:199). This passage (1:21-26) is based on the Gattung of the city lament and commences with the outcry '[h]ow the faithful town has become ...' (1:21). The lament confronts the present state of the city ('harlot/ murderers') with its past ('faithful/filled with justice/ righteousness'). The city's honorary titles builds a chiastic form around the city lament: 'faithful town/full of justice/ righteousness dwelt in her' (1:21) and 'city of righteousness/ faithful town' (1:26). By presenting the iniquities that now characterise the city, verses 21-23 explain why the city has lost its name: murder, rebellion, robbery, bribery, violation of justice (Beuken 2004:465).

Isaiah $1: 27$, which explicitly mentions 'Zion's repenters', is built upon the oracle of 1:21-26, which describes the purging of Zion with the end result of an explicit difference in the outcome for repenters on the one hand and for sinners on the other hand (1:27). In 1:27-31 the portrayal of the consequences of conduct - just as in 1:21-26 - places a stronger emphasis on the negative outcomes of non-repentance (1:28-31) and less of a focus on a description of the positive outcomes and turnaround of repentance (1:27). Whereas 1:28-31 begins with a general portrayal of the result for those who refuse to repent (1:28), the text changes dramatically in the concluding verses. This text actually concludes with an oracle that is directed specifically towards the non-repenters (1:29-31) (Carr 1996:201).

Manifestly, there is one major theme that occurs in the BI as a whole, specifically YHWH's interest in and devotion to the city of Zion, as we have clearly noticed in the preceding discussions of Isaiah 1 . The BI is characterised by its interest in the fate of Jerusalem or Zion, as well as the eschatological hopes linked to the notion of Zion. The BI develops this concern for Zion, which provides theological cohesion as well as giving this book its unitary stamp (Dumbrell 1985:112). The Isaianic prophecy appropriately concludes with a sketch of the emergence of a New Jerusalem, which is
YHWH's holy mountain. The whole world will go up to the New Jerusalem in a pilgrimage of worship (Is. 66:20-24). According to the final chapters of the prophecy, it is it clear:

... that the notion of the New Jerusalem is intimately linked with the prophecy of a New Creation (Is. 65:17-18). This New Jerusalem in fact functions as a symbol of the new age and is presented in the conclusion in obvious contrast to the city with which the book has begun. (Dumbrell 1985:112)

The promise of Zion's purification, as described in Isaiah 1, is followed by 'the word which Isaiah the son of Amos saw concerning Judah and Jerusalem' (Is. 2:1-5) (Beuken 2003, 2004:467; Williamson 2006). ${ }^{7}$ These verses tell of the vision of an ideal Zion, which will become the epicentre of God's rule of the whole Earth leading to the promotion of peace. If Isaiah $1: 1-2: 5$ is read synchronically, the addition of these verses to the BI leads to the coexistence of two themes, namely on the one hand, the 'cleansing of Zion' in chapter 1 and, on the other hand, the 'pilgrimage of the nations' (2:2-4). The precondition for the international pilgrimage to the mountain of YHWH and to the house of the God of Jacob in order to receive Torah $^{8}$ (2:3) is the purification of Zion - the separation of sinners and the righteous. What the nations will find here in Zion is not a set of cultic-religious rules but a God who acts as a fair judge and will arbitrate between them in order to stop war between them (Berges 2012a:28, 2012b:58). What is the role of the people of God in this city? They are the ones who are committed to $\mathrm{YHWH}$ and are the remnants of Israel, Jerusalem and the nations. Non-negotiable qualities needed for the city and its inhabitants include justice, righteousness and obedience (Watts 2005:50). The concluding invitation, '[o] house of Jacob, come, let us walk in the light of the Lord!' (Is. 2:5), furthermore illustrates the perspective of the community of the remnant, the we-group. According to them, 'the salvific future can only dawn when Jacob turns away from his sin and towards $\mathrm{YHWH}$ and his righteousness. The free gift of Torah is taken as a task to be fulfilled' (Berges 2012a:28).

\section{Conclusion}

The first opening of the BI (1:1-2:5) presents the renewal of the city of Zion and its population as an all-encompassing act of YHWH's dealings with his people. Isaiah 1 is the key to the understanding of the BI. It presents the reader with the picture of a decadent Jerusalem and contains a threat against the city, its inhabitants and its leaders. The physical and moral ruin of the nation will be reversed. This programme of restoration will focus on the symbols of the city that are lacking: faithfulness, justice and righteousness. YHWH will therefore interfere in the city's current affairs and choose sides with the oppressed against the perpetrators of injustice. When this goal is achieved, Isaiah 2:1-5 outlines the prophetic hope for Zion, which, if the city returns to its original righteousness and is redeemed, will cause a pilgrimage of the nations to Zion to receive YHWH's Torah here.

7.The following text is partly based on a previous publication: Groenewald (2013a:5-6).

8.For an outline of Torah in 1:1-2:5 see Groenewald (2013b). 


\section{Acknowledgements Competing interests}

The author declares that he has no financial or personal relationships that may have inappropriately influenced him in writing this article.

\section{References}

Berges, U., 2012a, Isaiah. The prophet and his book, Sheffield Phoenix Press, Sheffield. Berges, U., 2012b, The book of Isaiah. Its composition and final form, Sheffield Phoenix Press, Sheffield. (Hebrew Bible Monographs 46).

Beuken, W.A.M., 2003, Jesaja 1-12, Herder, Freiburg i.Br. (Herders Theologischer Kommentar zum Alten Testament).

Beuken, W.A.M., 2004, 'The literary emergence of Zion as a city in the first opening of the book of Isaiah $(1,1-2,5)$ ', in M. Witte (Hg.), Gott und Mensch im Dialog. Festschrift für Otto Kaiser zum 80. Geburtstag, pp. 457-470, Walter de Gruyter, Berlin. (Beihefte zur Zeitschrift für die alttestamentliche Wissenschaft 345/I-II).

Carr, D.M., 1996, 'Reading Isaiah from beginning (Isaiah 1) to end (Isaiah 65-66): Multiple modern possibilities', in R.F. Melugin \& M.A. Sweeney (eds.), New visions of Isaiah, pp. 188-218, Sheffield Academic Press, Sheffield. (Journal for the Study of Old Testament suppl. ser. 214).

Carr, D.M., 2011, 'Reading into the gap: Refractions of trauma in Israelite prophecy', in B.E. Kelle, F.R. Ames \& J.L. Wright (eds.), Interpreting exile. Displacement and deportation in Biblical and modern contexts, pp. 295-308, Society of Biblical Literature, Atlanta, GA. (Ancient Israel and its Literature 10).

Carr, D.M., 2014, Holy resilience. The Bible's traumatic origins, Yale University Press, New Haven, CT.

Carroll R. (Rhodas), M.D., 2009, 'Failing the vulnerable: The prophets and social care', in J.A. Grant \& D.A. Hughes (eds.), Transforming the world? The gospel and social responsibility, pp. 35-50, InterVarsity Press, Nottingham.

Childs, B.S., 2001, Isaiah, Westminster John Knox Press, Louisville, KY. (Old Testament Library).

Conrad, E.W., 1991, Reading Isaiah, Fortress Press, Minneapolis, MN. (Overtures to Biblical Theology 27).

Conrad, E.W., 1996, 'Prophet, redactor and audience: Reforming the notion of Isaiah's formation', in R.F. Melugin \& M.A. Sweeney (eds.), New visions of Isaiah, pp. 306-326, Sheffield Academic Press, Sheffield. (Journal for the Study of Old Testament suppl. ser. 214).

Conrad, E.W., 2003, Reading the latter prophets. Toward a new canonical criticism, T\&T Clark, London. (Journal for the Study of Old Testament suppl. ser. 376).

Dumbrell, W.J., 1985, 'The purpose of the book of Isaiah', Tyndale Bulletin 36, 111-128.
Fohrer, G., 1962, 'Jesaja 1 als Zusammenfassung der Verkündigung Jesajas', Zeitschrift für die alttestamentliche Wissenschaft 74, 251-268. http://dx.doi.org/10.1515/ zatw.1962.74.3.251

Groenewald, A., 2011, 'Isaiah 1:2-3, ethics and wisdom. Isaiah 1:2-3 and the Song of Moses (Dt 32): Is Isaiah a prophet like Moses?', HTS Teologiese Studies/ Theological Studies 67(1), Art. \#954, 1-6. http://dx.doi.org/10.4102/hts. v67i1.954

Groenewald, A., 2013a, 'An exegetical analysis of the vision of peace in the book of Isaiah (2:1-5)', Verbum et Ecclesia 34(2), Art. \#866, 1-7. http://dx.doi. org/10.4102/ve.v34i2.866

Groenewald, A., 2013b, 'The significance of תורה (Isa 2:3) within Isaiah 2:1-5: The relationship of the first overture (1:1-2:5) to the book's conclusion (Isa 65-66)' Old Testament Essays 26(3), 695-717.

Holladay, W.L., 1978, Isaiah. Scroll of a prophetic heritage, William B. Eerdmans, Grand Rapids, MI.

Kizhakkayil, S.J., 2016, YHWH's rebellious, wicked sons and the unfaithful daughter Zion. An intertextual and exegetical study of the prologue of Isaiah (Isa 1:1-31), Unpublished doctoral thesis, University of Innsbruck.

Leclerc, T.L., 2001, Yahweh is exalted in justice. Solidarity and conflict in Isaiah, Fortress Press, Minneapolis, MN.

Melugin, R.F., 1996, 'Figurative speech and the reading of Isaiah 1 as scripture', in R.F. Melugin \& M.A. Sweeney (eds.), New visions of Isaiah, pp. 282-305, Sheffield Academic Press, Sheffield. (Journal for the Study of Old Testament suppl. ser. 214).

Nissinen, M., (ed.), 2000, Prophecy in its Ancient Near Eastern context. Mesopotamian, Biblical, and Arabian perspectives, Society of Biblical Literature, Atlanta, GA. (Symposium Series 13).

Nissinen, M., (ed.), 2003, Prophets and prophecy in the Ancient Near East. Society of Biblical Literature, Atlanta, GA. (Writings from the Ancient World 12).

Oswalt, J.N., 1986, The book of Isaiah. Chapters 1-39, Eerdmans Publishing, Grand Rapids, MI. (New International Commentary on the Old Testament).

Routledge, R., 2004, 'Is there a narrative substructure underlying the book of Isaiah?', Tyndale Bulletin 55(2), 183-204.

Smith-Christopher, D.L., 2015, Micah. A commentary, Westminster John Knox Press, Louisville, KY. (Old Testament Library).

Stökl, J., 2012, Prophecy in the Ancient Near East: A philological and sociological comparison, Brill, Leiden. (Culture and History of the Ancient Near East 56).

Stulman, L. \& Kim, H.C.P.K, 2010. You are my people. An introduction to prophetic literature, Abingdon Press, Nashville.

Sweeney, M.A., 1996, Isaiah 1-39 with an introduction to prophetic literature, Eerdmans, Grand Rapids, MI. (Forms of Old Testament Literature 16).

Tull, P.K., 2010, Isaiah 1-39; Smyth \& Helwys, Macon, GA. (Smyth \& Helwys Bible Commentary).

Watts, J.D.W., 2005, Isaiah 1-33, rev. edn., Thomas Nelson, Nashville, TN. (WBC 24).

Williamson, H.G.M., 2006, Isaiah 1-5, T\&T Clark, London. (ICC). 